\title{
Analisis Faktor Yang Menghambat Penemuan Suspek Penderita Tuberkulosis di Puskesmas X
}

\section{Analysis of Factors Inhibiting Invention Tuberculosis Patient Suspect in Community Health Center}

Gita Sekar Prihanti ${ }^{1}$, Nindya Puspita Sari ${ }^{2}$, Devita Ari Pratiwi², Laily Putri Mabruukah², Dwi Hutami Sekarwangi², Wildan Firmansyah ${ }^{2}$, Mutiara Vallentin Cynthiana ${ }^{2}$, Rizdianis Devi Masyithoh ${ }^{2}$

${ }^{1}$ Staf Pengajar, Fakultas Kedokteran, Universitas Muhammadiyah Malang

${ }^{2}$ Mahasiswa, Fakultas Kedokteran, Universitas Muhammadiyah Malang

Fakultas Kedokteran Universitas Muhammadiyah Malang. Jl. Bendungan Sutami 188A Malang

\begin{abstract}
Abstrak
Latar Belakang: Dalam upaya menurunkan angka kesakitan dan kematian yang diakibatkan penyakit menular seperti tuberculosis, Indonesia menggunakan strategi DOTS untuk skiring dan penemuan kasus TB. Pada tahun 2014 jumlah kasus baru BTA (+) sebanyak 176.677 kasus. Nilai keberhasilan dari kasus TB ditentukan dari nilai penemuan kasus yaitu 70\% dari jumlah penduduk. di puskesmas X didapatkan hanya sebesar $43 \%$ dari target. Penelitia ini bertujuan menganalisis faktor yang menghambat penemuan suspek penderita tuberkulosis di wilayah kerja puskesmas X Kota Y.
\end{abstract}

Metode: Desain cross sectional dengan melibatkan 250 orang.

Hasil Penelitian: Hasil uji multivariat dengan regresi logistik menunjukkan bahwa terdapat enam variabel yang mempunyai pengaruh signifikan terhadap penemuan kasus suspek TB, yaitu usia $>35$ tahun $(p=0.000)$ dengan nilai OR 8,620, gejala awal batuk $(p=0.017)$ dengan nilai OR 3.119, fasilitas kesehatan yang dituju $(\mathrm{p}=0.000)$ dengan nilai $\mathrm{OR} 0.167$, stigma rendah $(\mathrm{p}=0.001)$ dengan nilai OR 3.005, pengetahuan kurang $(\mathrm{p}=0.000)$ dengan nilai OR 8.763 , dan status ekonomi rendah $(\mathrm{p}=0.042)$ dengan nilai OR 0.427. Berdasarkan nilai Nagelkerke R square yaitu 0,419 (41,9\%), menunjukkan bahwa sebesar 41,9\% penghambat penemuan kasus suspek TB dijelaskan oleh enam variabel yang berhubungan tersebut, sedangkan 58,1\% merupakan faktor penghambat yang dapat dijelaskan oleh variabel lain yang belum diteliti dalam penelitian ini seperti pengaruh kader TB atau pelayanan kesehatan.

Simpulan : Faktor yang menghambat penemuan suspek TB yaitu usia $>35$ tahun, gejala awal batuk, fasilitas kesehatan yang dituju, stigma rendah, pengetahuan kurang, dan status ekonomi rendah.

Kata Kunci : penghambat penemuan kasus suspek TB, TB Paru, Puskesmas X Kota Y. 


\section{Abstract}

Background : Indonesia's efforts to reduce morbidity and mortality diseases conduct disease control programs, especially infectious diseases such as tuberculosis with DOTS strategy. In 2014 the number of new cases of smear $(+)$ as many as 176,677 cases. The success rate of TB cases determined from the discovery of a case that is $70 \%$ of the population. in Community Heatlh Center X obtained only $43 \%$ of the target. The aim to analysis of the factors that hinder the discovery of suspected tuberculosis in working area Community Health Center of X Kediri City.

Methods : cross sectional design study involve of 250 people.

Results : The test results of multivariate logistic regression showed that there are six variables that have a significant influence on the discovery of suspected tuberculosis cases, the age $>35$ years $(p=0.000)$ with OR 8.620, the early symptoms of cough $(\mathrm{p}=0.017)$ with OR 3.119 , facilities health destination $(\mathrm{p}=$ $0.000)$ with OR 0.167 , lower stigma $(p=0.001)$ with OR 3,.05, less knowledge $(p=0.000)$ with OR 8.763, and the lower economic status $(\mathrm{p}=0.042)$ with OR 0.427. Based Nagelkerke $\mathrm{R}$ square value is 0.419 $(41.9 \%)$, it shows that $41.9 \%$ of TB suspect cases inhibitors of the invention described by the six variables related, while $58.1 \%$ are factors that can be explained by other variables has not been studied in this research such as TB or influence cadre of health services.

Conclusion : Factor inhibiting invention tuberculosis patient suspect are age $>35$ years, the early symptoms of cough, health care facilities targeted, low stigma, lack of knowledge, and low economic status.

Keywords : inhibitors of the invention of suspected tuberculosis cases, pulmonary tuberculosis, community health center of X Kediri City.

\section{PENDAHULUAN}

Indonesia merupakan negara yang memiliki kepadatan penduduk yang tinggi. Pusat Data dan Informasi Kementrian Kesehatan melaporkan jumlah penduduk pada tahun 2014 sebesar 252.124.458 jiwa. (Sekjen Kemenkes RI, 2015) menurunkan angka kesakitan dan kematian penyakit diperlukan program pengendalian penyakit terutama penyakit menular seperti tuberkulosis (Sekjen Kemenkes RI, 2015). indikator yang digunakan untuk menilai keberhasilan program TB salah satunya yakni indikator penemuan kasus (PUSADATIN, 2015).

Menurut target yang diterapkan oleh MDGs tahun 2015 tentang target nasional yang berkaitan dengan upaya pengendalian TB mengenai proporsi jumlah kasus TB yang terdeteksi dalam program DOTS yaitu $70 \%$.
Berdasarkan data yang diperoleh di Puskesmas X Kota Y pada tahun 2015 terjadi persentase penemuan suspek penderita TB yang masih rendah yakni sebanyak 43\% (PNPT, 2014).

Beberapa faktor yang memiliki hubungan yang dengan penghambatan penemuan kasus suspek TB paru misalnya jenis pekerjaan, gejala awal yang muncul, pelayanan kesehatan yang pertama kali pasien kunjungi, jarak antara rumah terhadap pelayanan kesehatan dan juga stigma pasien terhadap penyakit TB (Nasution, 2015).

Berdasarkan penjelasan masalah yang telah diperoleh maka penulis ingin meneliti tentang "Analisis faktor yang menghambat penemuan suspek penderita TB di wilayah kerja Puskemas X Kota Y”. 


\section{METODE PENELITIAN}

Jenis penelitian ini adalah penelitian analitik observasional dengan rancangan penelitian cross-sectional.

Penelitian dilaksanakan pada 2016 di Puskesmas X Kota Y. Populasi dalam penelitian ini terdiri dari seluruh penderita presumtif/terduga TB di Wilayah Kerja Puskesmas X.

Sampel dalam penelitian ini terdiri dari seluruh penderita presumtif/terduga TB di Wilayah Kerja Puskesmas X yang memenuhi kriteria inklusi dan eksklusi yang berjumlah 250 orang.
Metode pengumpulan data dalam penelitian ini melalui pengambilan data primer menggunakan kuisioner dan Focussed Group Disscussion. Setelah itu dilakukan pengolahan data.

\section{HASIL}

Pada penelitian ini, data yang diperoleh merupakan data primer yang diambil melalui wawancara kuesioner.

Berdasarkan tabel 1 menunjukkan bahwa sebagian besar responden mengaku memeriksakan sputum dan tidak memeriksakan sputum saat memiliki gejala suspek TB yaitu sebanyak $50 \%$ dan $50 \%$.

Tabel 1 Distribusi Frekuensi Berdasarkan Suspek yang Periksa Sputum

\begin{tabular}{ccc}
\hline Suspek yg Periksa & N & $\%$ \\
\hline Periksa & 125 & 50 \\
\hline Tidak Periksa & 125 & 50 \\
\hline Total & 250 & 100.0 \\
\hline
\end{tabular}

Tabel 2 Distribusi Frekuensi Berdasarkan Usia

\begin{tabular}{ccc}
\hline Usia & $\mathrm{N}$ & $\%$ \\
\hline $15-35$ tahun & 106 & 42.4 \\
\hline$>35$ tahun & 144 & 57.6 \\
\hline Total & 250 & 100.0
\end{tabular}

Berdasarkan tabel 2, dari 250 responden didapatkan bahwa sebagian besar responden mempunyai usia $>35$ tahun sejumlah 144 responden dengan persentase sebesar $57.6 \%$.
Berdasarkan tabel 3 menunjukkan bahwa responden dengan jenis kelamin perempuan memiliki jumlah yang lebih besar dari responden dengan jenis kelamin laki - laki yaitu sebanyak 144 responden $(57.6 \%)$.

Tabel 3 Distribusi Frekuensi Berdasarkan Jenis Kelamin

\begin{tabular}{ccc}
\hline Jenis Kelamin & N & $\%$ \\
\hline Laki-laki & 106 & 42.4 \\
\hline Perempuan & 144 & 57.6 \\
\hline Total & 250 & 100.0 \\
\hline
\end{tabular}


Tabel 4 Distribusi Frekuensi Berdasarkan Tingkat Pendidikan

\begin{tabular}{ccc}
\hline Pendidikan & $\mathrm{N}$ & $\%$ \\
\hline Tidak sekolah & 18 & 7.2 \\
\hline SD/SMP/SMA & 182 & 72.8 \\
\hline Universitas & 50 & 20 \\
\hline Total & 250 & 100.0 \\
\hline
\end{tabular}

Berdasarkan tabel 4 menunjukkan bahwa sebagian besar responden memiliki latar belakang pendidikan terakhir SD/SMP/SMA sebesar 182 responden (72.8\%). Berdasarkan tabel 5 menunjukkan bahwa sebagian besar responden mengaku memeliki pekerjaan sehari-hari yaitu sebanyak 163 responden (65.2\%). Berdasarkan tabel 6 menunjukkan bahwa sebagian besar responden memiliki keluhan batuk sebagai gejala yang muncul pertama kali sebelum penderita berobat ke fasilitas pelayanan kesehatan yaitu $216(86.4 \%)$. Berdasarkan tabel 7 menunjukkan bahwa sebagian besar responden lebih memilih ke fasilitas pelayanan kesehatan yaitu $183(73.2 \%)$. Berdasarkan tabel 8 menunjukkan bahwa sebagian besar jarak rumah responden dengan puskesmas sekitar $1-<2 \mathrm{~km}(44 \%)$. Berdasarkan tabel 9 menunjukkan bahwa sebagian besar responden memiiki stigma rendah sebesar 156 responden (62.4\%). Berdasarkan tabel 10 menunjukkan bahwa sebagian besar responden memiliki tingkat pengetahuan yang baik yaitu 126 responden $(50.4 \%)$.

Tabel 5 Distribusi Frekuensi Berdasarkan Pekerjaan

\begin{tabular}{ccc}
\hline Pekerjaan & $\mathrm{N}$ & $\%$ \\
\hline $\begin{array}{c}\text { Tidak } \\
\text { bekerja }\end{array}$ & 87 & 34.8 \\
\hline Bekerja & 163 & 65.2 \\
\hline Total & 250 & 100.0 \\
\hline
\end{tabular}

Tabel 6 Distribusi Frekuensi Berdasarkan Gejala Awal yang Pertama Kali Muncul

\begin{tabular}{ccc}
\hline Gejala Awal & $\mathrm{N}$ & $\%$ \\
\hline Batuk & 216 & 86.4 \\
\hline Batuk Darah & 34 & 13.6 \\
\hline Demam & 0 & 0.0 \\
\hline Penurunan BB & 0 & 0.0 \\
\hline Nyeri Dada & 0 & 0.0 \\
\hline Total & 250 & 100.0 \\
\hline
\end{tabular}

Tabel 7 Distribusi Frekuensi Berdasarkan Pelayanan Kesehatan yag Dituju

\begin{tabular}{ccc}
\hline Yankes & $\mathrm{N}$ & $\%$ \\
\hline Faskes & 183 & 73.2 \\
\hline Non-faskes & 67 & 26.8 \\
\hline Total & 250 & 100.0 \\
\hline
\end{tabular}


Tabel 8 Distribusi Frekuensi Berdasarkan Jarak ke Fasilitas Kesehatan

\begin{tabular}{ccc}
\hline Jarak & $\mathrm{N}$ & $\%$ \\
\hline$<1 \mathrm{~km}$ & 17 & 6.8 \\
\hline $1-<2 \mathrm{~km}$ & 110 & 87.9 \\
\hline $2-<3 \mathrm{~km}$ & 102 & 40.8 \\
\hline$>5 \mathrm{~km}$ & 21 & 8.4 \\
\hline Total & 372 & 100.0
\end{tabular}

Tabel 9 Distribusi Frekuensi Berdasarkan Stigma

\begin{tabular}{ccc}
\hline Stigma & $\mathrm{N}$ & $\%$ \\
\hline Tinggi & 94 & 37.6 \\
\hline Rendah & 156 & 62.4 \\
\hline Total & 250 & 100.0 \\
\hline
\end{tabular}

Tabel 10 Distribusi Frekuensi Berdasarkan Tingkat Pengetahuan

\begin{tabular}{ccc}
\hline Pengetahuan & $\mathrm{N}$ & $\%$ \\
\hline Baik & 126 & 50.4 \\
\hline Kurang & 124 & 49.6 \\
\hline Total & 250 & 100.0 \\
\hline
\end{tabular}

Tabel 11 Distribusi Frekuensi Berdasarkan Status Ekonomi

\begin{tabular}{ccc}
\hline St. Ekonomi & $\mathrm{N}$ & $\%$ \\
\hline Miskin & 51 & 20.4 \\
\hline Tidak miskin & 199 & 79.6 \\
\hline Total & 250 & 100.0 \\
\hline
\end{tabular}

Tabel 12 Distribusi Frekuensi Berdasarkan Sumber Media Informasi

\begin{tabular}{ccc}
\hline Sumber informasi & $\mathrm{N}$ & $\%$ \\
\hline Media informasi & 53 & 21.2 \\
\hline Edukasi & 51 & 20.4 \\
\hline Teman/keluarga & 107 & 42.8 \\
\hline Penderita TB & 39 & 15.6 \\
\hline Total & 250 & 100.0 \\
\hline
\end{tabular}

Berdasarkan tabel 11 menunjukkan bahwa sebagian besar memiliki tingkat status ekonomi responden tidak miskin yaitu 199 responden (79.6\%). Berdasarkan tabel 12 menunjukkan bahwa sebagian besar responden mengetahui tentang TB melalui teman atau keluarga yaitu sebesar 107 responden (42.8\%).
Berdasarkan tabel 13 diketahui hasil uji chisquare pada analisis bivariat menunjukkan bahwa terdapat lima variabel yang mempunyai pengaruh signifikan terhadap penghambatan penemuan kasus $T B$, yaitu usia $(p=0,000)$, gejala pertama kali muncul $(\mathrm{p}=0,041)$, pelayanan kesehatan 
yang dituju $(p=0,000)$, stigma $(p=0,050)$, dan

tingkat pengetahuan TB $(\mathrm{p}=0,008)$.

Tabel 13 Analisis Bivariat antara Variabel Independen terhadap Dependen

\begin{tabular}{ccc}
\hline Variabel & $\mathbf{p}$ & Keterangan \\
\hline Usia & 0,000 & Bermakna \\
\hline Jenis Kelamin & 0,055 & Tak bermakna \\
\hline Pendidikan & 0,803 & Tak bermakna \\
\hline Pekerjaan & 0,595 & Tak bermakna \\
\hline Gejala Awal & 0,041 & Bermakna \\
\hline Faskes yg dituju & 0,000 & Bermakna \\
\hline Jarak ke Faskes & 0,351 & Tak bermakna \\
\hline Stigma & 0,050 & Bermakna \\
\hline $\begin{array}{c}\text { Tingkat } \\
\text { Pengetahuan }\end{array}$ & 0,008 & Bermakna \\
\hline Status Ekonomi & 0,059 & Tak bermakna \\
\hline Sumber Informasi & 1,000 & Tak bermakna
\end{tabular}

\section{PEMBAHASAN}

Dari hasil penelitian ini, dari 250 responden didapatkan bahwa responden mengaku memeriksakan sputum dan tidak memeriksakan sputum saat memiliki gejala suspek TB yaitu sebanyak $50 \%$ dan $50 \%$. Hal ini masih belum memenuhi target suspek yang memeriksakan sputum yang ditetapkan yakni $70 \%$.

Penghambatan penemuan suspek penderita TB secara bermakna dikaitkan dengan bertambahnya usia penderita. Hal ini karena semakin lama masyarakat semakin mengetahui mengenai TB. Berdasarkan dari hasil penelitian didapatkan sebagian besar responden mempunyai usia $>35$ tahun $(57,6 \%)$. Sementara itu, pada usia 15-35 tahun mengalami penurunan (42,4\%). Hal tersebut sesuai dengan Choudhari (2012) bahwa penghambatan penemuan pasien suspek ditemukan pada usia $>50$ tahun. Sedangkan pada penelitian Tauseef (2011) menjelaskan bahwa usia dapat menghambat penemuan kasus suspek TB dimana terjadi pada usia produktif yaitu 15-35 tahun.

Berdasarkan dari hasil penelitian didapatkan sebagian besar responden dengan jenis kelamin perempuan memiliki jumlah yang lebih besar dari responden dengan jenis kelamin laki - laki yaitu sebanyak 144 responden (57.6\%). Sedangkan laki-laki sebanyak 106 responden
$(42,4 \%)$. Dari uji pada penelitian ini, jenis kelamin tidak memiliki pengaruh untuk menjadi faktor yang dapat menghambat penemuan kasus TB. Hal sesuai dengan penelitian Osei (2015) bahwa tidak terdapat hubungan yang signifikan antara jenis kelamin dengan penemuan kasus suspek TB.

Pendidikan berarti bimbingan yang diberikan seseorang terhadap perkembangan orang lain menuju kearah cita-cita tertentu yang menentukan manusia untuk berbuat sesuatu dan mengisi kehidupan dalam mencapai kebahagian dan keselamatan, pendidikan diperlukan dalam mendapatkan informasi, misalnya informasi tentang penyakit TB (Aritonang, 2014). Berdasarkan hasil pada penelitian ini menunjukkan bahwa sebagian besar responden memiliki latar belakang pendidikan terakhir SD/SMP/SMA yaitu sebanyak 72,8 \%, namun tidak memiliki hubungan dengan penghambatan penemuan suspek TB dikarenakan nilai $\mathrm{p}=$ 0,803 . Hal ini sesuai dengan penelitian Laohasiriwong (2016) bahwa tingkat pendidikan tidak mempengaruhi penemuan kasus suspek TB $(p=0.511)$ karena pendidikan tinggi atau rendah tidak mempengaruhi keinginan individu untuk memeriksakan kondisi tubuhnya.

Berdasarkan data univariat menunjukkan bahwa sebagian besar responden mengaku memeliki pekerjaan sehari-hari yaitu sebanyak 
163 responden $(65.2 \%)$. Dengan nilai $\mathrm{p}=0,595$, nilai ini bermakna bahwa tidak terdapat hubungan dengan hambatan penemuan kasus suspek TB. Hal ini sesuai dengan Osei (2015) bahwa hasil penelitiannya (pekerjaan) tidak mempengaruhi penemuan kasus.

Berdasarkan uji statistika yang digunakan maka diperoleh menunjukkan bahwa sebagian besar responden memiliki keluhan batuk sebagai gejala yang muncul pertama kali sebelum penderita berobat ke fasilitas pelayanan kesehatan yaitu 216 (86.4\%), dengan nilai $\mathrm{p}=$ $0,041(\mathrm{p}<0,05)$ bermakna bahwa gejala yang pertama kali muncul memiliki nilai yang signifikan. Hal ini sesuai dengan penelitian Cai (2015) bahwa gejala yang pertama kali muncul mempengaruhi penemuan kasus suspek TB terutama gejala batuk berdarah.

Fasilitas pelayanan kesehatan yang dituju merupakan salah satu faktor penghambat penemuan kasus suspek TB dimana pada penelitian ini responden sebagian besar lebih memilih ke fasilitas kesehatan yang memiliki tenaga dokter yaitu 183 responden (73.2\%), dengan nilai $\mathrm{p}=0,000$ yang berarti memiliki hubunan antara layanan kesehatan dengan penemuan kasus suspek dengan nilai Odds Ratio sebesar 0,182. Hasil ini sesuai dengan penelitian Sreeramareddy (2014) bahwa penemuan kasus dapat dipengaruhi oleh pelayanan kesehatan yang dituju pertama kali.

Sebagian besar jarak rumah responden dengan puskesmas sekitar $1-<2 \mathrm{~km}(44 \%)$ dengan nilai bivariat sebesar $\mathrm{p}=0,351$ dimana nilai ini bermakna bahwa jarak tidak memiliki nilai yang signifikan pada penemuan kasus suspek TB. Hal ini sesuai dengan penelitian Laohasiriwong (2016) bahwa jarak tidak memiliki hubungan dengan penemuan kasus suspek TB. Hal ini dikarenakan kemudahan akses jalan akibat banyak kendaraan dan adanya fasilitas kesehatan terdekat.

Dari data menunjukkan bahwa sebagian besar responden memiiki stigma rendah sebesar 156 responden $(62.4 \%)$ dengan nilai p sebesar $0,050$ ( $\mathrm{p}<0,050)$ hal ini menunjukan bahwa stigma memiliki nilai yang signifikan terhadap penemuan kasus. Dengan demikian stigma rendah dapat menghambat penemuan kasus suspek TB. Hal ini sesuai dengan penelitian $\mathrm{Li}$ Ying (2013) bahwa rendahnya stigma dapat mempengaruhi penemuan kasus suspek TB. Stigma rendah ini dapat mengakibatkan seseorang enggan untuk memeriksakan dirinya dikarenakan malu dan takut untuk mengetahui penyakit pada tubuhnya.

Dari data sebelumnya menunjukkan bahwa sebagian besar responden memiliki tingkat pengetahuan yang kurang yaitu 126 responden (50.4\%), pada uji chi square didapatkan nilai $\mathrm{p}$ sebesar 0,008 dimana nilai ini bermakna bahwa pengetahuan memiliki nilai yang signifikan dengan penemuan kasus suspek TB, dimana diketahui bahwa pengetahuan kurang dapat menghambat penemuan kasus suspek TB. Hal ini sesuai dengan penelitian Li Ying 2013 bahwa pengetahuan yang rendah dapat mempengaruhi penemuan kasus suspek TB. Pengetahuan yang rendah ini menyebabkan penderita yang memiliki gejala batuk lama tidak mengetahui kemungkinan penyakit apa yang sedang ia alami.

Berdasarkan data sebelumnya menunjukkan bahwa sebagian besar memiliki tingkat status ekonomi responden tidak miskin yaitu 199 responden $(76.9 \%)$ dengan nilai $\mathrm{p}=$ 0,042 yang bermakna bahwa status ekonomi memiliki nilai yang signifikan dengan penemuan kasus suspek TB. Hal ini sesuai dengan penelitian Cai 2015 bahwa status ekonomi rendah berpengaruh pada penghambatan penemuan kasus suspek TB. Ekonomi rendah memaksa seseorang yang memiliki masalah kesehatan lebih memilih fokus untuk mendapatkan penghasilan sehari-hari demi keluarganya daripada terhadap kesehatan sendiri.

Dari perhitungan sebelumnya didapatkan sebagian besar responden mengetahui tentang TB melalui teman atau saudara yaitu sebesar 107 responden $(42.8 \%)$, dengan nilai $\mathrm{p}=1,000$ dimana nilai ini bermakna bahwa sumber informasi tidak memiliki nilai yang signifikan dengan penemuan kasus suspek TB. Hal ini sesuai dengan penelitian Chizimba (2015) bahwa tidak terdapat hubungan antara sumber informasi dan persepsi tinggi dari risiko pada TB, dimana jika seseorang mendapatkan sumber informasi dari berbagai pihak mengenai suatu 
kejadian atau peristiwa secara baik namun persepsi orang tersebut masih rendah pada suatu permasalahan, hal tersebut tetap menjadikan seseorang ketakutan bila orang tersebut terdiagnosis penyakit yang serius dan dapat menimbulkan keinginan tidak memeriksakan kondisi kesehatannya (Tarimo, 2012).

Berdasarkan hasil uji multivariat menggunakan regresi logistik didapatkan hasil bahwa ada 6 faktor yang berhubungan dengan penghambatan penemuan suspek TB. Nilai sig setiap variabel menunjukkan usia 0,000, gejala awal 0,017, pelayanan kesehatan yang pertama kali dituju 0,000, stigma tentang TB 0,001, pengetahuan 0,000 , status ekonomi 0,042 dimana semua variabel tersebut memiliki nilai $\mathrm{Sig}$ lebih kecil dari nilai alpha 0,05 yang artinya variabel usia, gejala awal, pelayanan kesehatan yang pertama kali dituju, stigma tentang TB, pengetahuan serta status ekonomi berpengaruh untuk menghambat penemuan kasus suspek TB. Sedangkan pada variabel jenis kelamin, pendidikan, pekerjaan, jarak ke fasilitas kesehatan, dan sumber informasi tidak berpengaruh secara signifikan terhadap pennghambatan penemuan kasus suspek TB.

Hasil uji multivariat dan bivariat dalam penelitian ini terdapat sedikit perbedaan. Misalnya pada faktor status ekonomi. Berdasarkan hasil uji bivariat didapatkan bahwa status ekonomi tidak berpengaruh terhadap penghambatan penemuan kasus suspek TB, tetapi pada hasil multivariat menunjukkan hasil yang berbeda. Hal ini dapat terjadi karena banyak faktor yang mempengaruhi pola pikir masyarakat yang selalu terkait dengan masalah ekonomi. Hal ini sesuai dengan penelitian Cai 2015 bahwa status ekonomi rendah akan memaksa seseorang yang memiliki masalah kesehatan lebih memilih fokus untuk mendapatkan penghasilan seharihari demi keluarganya daripada terhadap kesehatan sendiri. Namun, ada faktor lain yang ikut berpengaruh dalam pengambilan keputusan untuk memeriksakan kondisi kesehatan. Misalnya, stigma mengenai penyakit TB yang masih rendah serta kurangnya pengetahuan.

Menurut Dahlan (2014), menilai faktor yang paling berpengaruh adalah dengan melihat nilai OR. Pada penelitian ini faktor yang paling berpengaruh adalah pengetahuan dengan nilai OR sebesar 8.763. Menurut Li Ying 2013 bahwa pengetahuan yang rendah dapat mempengaruhi penemuan kasus suspek TB karena pengetahuan yang rendah menyebabkan penderita yang memiliki gejala batuk lama tidak mengetahui kemungkinan penyakit apa yang sedang ia alami sehingga kesadaran untuk memeriksakan kesehatannya.

Berdasarkan hasil uji regresi logistik Nagelkerke didapatkan nilai R Square 0,419. Hal ini menunjukkan bahwa faktor-faktor yang berpengaruh dalam penelitian ini mempunyai nilai sebesar $0,419 \times 100 \%=41,9 \%$ dalam mempengaruhi penghambatan penemuan kasus suspek TB dari faktor pasien. Sedangkan 58,1\% sisanya merupakan faktor lain yang memiliki pengaruh juga terhadap penghambatan penemuan kasus suspek TB. Misalnya dari faktor pelayanan kesehatan seperti peran kader TB.

\section{SIMPULAN}

Beberapa permasalahan yang terjadi pada suspek penderita TB yang tidak periksa dahak di wilayah kerja Puskesmas X Kota Y adalah usia, jenis kelamin, pendidikan, pekerjaan, gejala awal yang muncul, pelayanan kesehatan yang pertama kali dituju, jarak terhadap fasilitas kesehatan, stigma, pengetahuan, status ekonomi serta sumber informasi.

Faktor-faktor dari pasien pada penelitian ini yang mempengaruhi penghambatan penemuan kasus supek TB yakni usia $>35$ tahun, gejala awal batuk, fasilitas kesehatan yang dituju, stigma rendah, pengetahuan kurang, dan status ekonomi rendah.

\section{DAFTAR PUSTAKA}

Alavi Sayed M, et al. 2014. Factors associated with delay in diagnosis and treatment of pulmonary tuberculosis. Jundishapur J Microbiol. March 8 (3) : e19238.

Amin, Z \& Bahar, A. 2010. Buku Ajar Ilmu Penyakit Dalam Jilid III Edisi V. Jakarta: InternaPublishing.

Aritonang ES. 2014. Faktor-faktor yang berhubungan dengan keterlambatan diagnosis pada penderita tuberculosis di 
kabupaten Kebumen tahun2013. Program pascasarjana FK UGM Yogyakarta.

Cai Jing, et al. 2015. Factors associated with patient and provider delays for tuberculosis diagnosis and treatment in asia : a systematic review and metaanalysis. PLOS ONE.

Chizimba R, et al. 2015. The Association Between Multiple Sources Of Information And Risk Perception Of Tuberculosis, Ntcheu District, Malawi. Research Article. PLOS

Choudhari M et al. 2012. Factor associated with patient delay in diagnosis of pulmonary tuberculosis in a district. Journal of Nepal Health Res Coune. 10 (22) : 234-8.

Dahlan Sopiyudin. 2014. Stastitika untuk Kesehatan dan Kedokteran : Deskriptif, Bivariat dan Multivariat Edisi 2 Cetakan 3. Jakarta : PT. Sagung Seto.

Dinas Kesehatan Kota Y. 2015. Profil Kesehatan Kota Y Tahun 2015. Kediri.

Dirjen PP dan PL. 2011. Strategi Nasional Pengendalian TB di Indonesia 2010 2014. Kementerian Kesehatan RI.

Faisal Sobia, et al. 2014. Socio-demographic factors affecting tuberculosis test seeking behavior in Pakistan : a review. Punjab Univ J Zool. Vol 29 (2), pp 91-6.

Fuad, I. 2005. Dasar - Dasar Pendidikan. Jakarta : PT. Rineka Cipta

Kemenkes RI. 2013. Pedoman Nasional Pelayanan Kedokteran Tata Laksana Tuberkulosis.

Laohasiriwong Wongsa, et al. 2016. Delay for first consultation and its associated factors among new pulmonaru tuberculosis patients of central Nepal. Hindawi publishing corporation tuberculosis research and treatment.

Li Ying, et al. 2013. Factor associated with patient and diagnostic delays in Chinese
TB patients : a systemic review and meta-analysis. BMC Medicine. 11 : 156.

Nasution, Dian IPS. 2015. Faktor - Faktor Yang Mempengaruhi Keterlambatan Diagnosis Tuberkulosis Paru Di Medan. Thesis Ppds Magister Departemen Pulmonologi Dan Ilmu Kedokteran Respirasi Fakultas Kedokteran Universitas Sumatra Utara/RS U Haji Adam Malik Medan

Osei Eric, et al. 2015. Factors associated with delay in diagnosis among tuberculosis patients in Hohoe Municipality, Ghana. BMC public health. 15 : 721 .

PNPT (Pedoman Nasional Pengendalian Tuberkulosis). 2014. Jakarta

PUSADATIN. 2015. Infodatin. Pusat Data dan Informasi Kementerian Kesehatan RI.

Sekjen Kemenkes RI. 2015. Profil Kesehatan Indonesia 2014. Kementerian Kesehatan Republik Indonesia.

Sreeramarreddy, CT et al. 2014. Delays in diagnosis and treatment of pulmonarytuberculosis in India : a systematic review. INT J TUBERC LUNG DIS. The Union. 1- 12.

Sujoko, E. Setiawati, EIP. \& Lestari, BW. 2012. Keterlambatan Diagnosis Tuberkulosis Paru. Thesis. Program Pascasarjana Universitas Padjadjaran.

Tarimo Gilbert B. 2012. Delay in seeking care among tuberculosispatients attending tuberculosis clinics in rungwe district, Tanzania. Master of public health dissertation Muhimbili University of Health and Allied Sciences.

Tauseef, A. 2011. causes of Delay in Diagnosis and Treatment of Pulmonary Tuberculosis in Gujrat, Pakistan. Tesis. Pakistan: Public Health Management Ritsumeikan Asia Pacific University.

WHO. 2006. Diagnostic and Treatment delay in tuberculoss. Cairo: World Health Organization. 